\title{
PROGNOSTIC SIGNIFICANCE OF CYTOREDUCTIVE THERAPY OF OVARIAN CANCER - EASTERN CROATIA EXPERIENCE
}

\author{
Zlatko Topolovec ${ }^{1}$, Teodora Horvat ${ }^{2}$, Domagoj Vidosavljević ${ }^{1,3}$, Siniša Šijanović ${ }^{1}$, \\ Andrijana Müller-Vranješ ${ }^{1}$, Margareta Ugljarević ${ }^{1}$, Dimitrije Milojković ${ }^{1}$ and Stjepan Topolovec ${ }^{4}$ \\ ${ }^{1}$ Department of Obstetrics and Gynecology, Faculty of Medicine, Josip Juraj Strossmayer University of Osijek, \\ Osijek, Croatia; ${ }^{2}$ Osijek University Hospital Centre, Osijek, Croatia; ${ }^{3}$ Department of Obstetrics and Gynecology, \\ Vukovar General Hospital, Vukovar, Croatia; ${ }^{4}$ Department of English Language and Literature, \\ Faculty of Humanities and Social Sciences, University of Zagreb, Zagreb, Croatia
}

\begin{abstract}
SUMMARY - The aim of this retrospective study was to present the impact of successful optimal cytoreductive therapy on the overall prognosis of ovarian cancer treatment. Several factors were analyzed, including clinical (stage, age and parity), histopathologic/cytological (histologic type and grade of tumors, cytological findings of ascites or peritoneal washout), and therapeutic (surgery performed with the degree of cytoreduction, adjuvant chemotherapy and response to therapy). The study included 126 patients treated during a 5-year period at the Department of Gynecology and Obstetrics, Osijek University Hospital Centre in Osijek. Patient age ranged from 29 to 82, total 5-year survival was $55.5 \%$ and median survival was 76.2 months. Optimal cytoreduction (residual tumor $<1 \mathrm{~cm}$ ) was performed in $49.2 \%$ of patients. On data analysis, the life chart method, $\chi^{2}$-test and Cox regression analysis were used. The level of significance was set at $\mathrm{p}<0.05$. Parity, histologic tumor grade, presence of malignant cells in ascites and peritoneal washout, as well as clinical stage yielded statistical significance on univariate analysis. Cytoreductive ovarian cancer therapy turned out to be a significant prognostic factor and on multivariate analysis proven to be an independent prognostic factor. Optimal cytoreduction, besides direct effect on survival, improved the quality of therapeutic response of the tumor to chemotherapy.
\end{abstract}

Key words: Ovarian neoplasms; Cytoreduction surgical procedures; Prognosis; Retrospective studies; Chemotherapy, adjuvant; Croatia

\section{Introduction}

Ovarian cancer is the sixth most common cancer among women in Croatia, with 432 newly reported cases in 2004 (rate 18.8/100 000) and 240 reported deaths (12.2/100 000). Most often, ovarian cancer occurs after menopause, especially among women after their sixties. In Croatia, the incidence and mortality rates caused by ovarian cancer are increasing ${ }^{1}$.

Correspondence to: Domagoj Vidosavljevic, $M D$, Department of Obstetrics and Gynecology, Vukovar General Hospital, Bolnička 5, HR-32000 Vukovar, Croatia

E-mail: domagoj.vidosavljevic@gmail.com

Received February 9, 2017, accepted September 15, 2017
Malignant epithelial ovarian tumors characteristically spread by implanting tumor fragments along the abdominal peritoneum, i.e. by transcoelomic spread. This typically occurs along the serosa of the lower abdominal cavity and small pelvis, in the subserous stromal tissue and adipose omentum tissue, and along the diaphragmatic serosa and Glisson liver capsule. Multiple implants may be separated fragments of the ovarian cancer, but it is believed that they may also be an expression of the localized (in situ) proliferation of the peritoneum, under the influence of the same carcinogenic agent that caused the development of epithelial ovarian cancer. 
Most authors today agree that the only prognostic factor effective in the treatment of ovarian cancer is surgical cytoreductive therapy. The exact stage of the condition can only be determined by a primary surgical approach, which also allows removal of as much tumor tissue as possible in order to create favorable conditions for further treatment with chemotherapy.

Complete reduction is achieved if there is no residual tumor left. Optimal cytoreduction is, according to Gynecologic Oncology Group (GOG) studies 114 and 172 started in 2001/2002 2,3 , the reduction of tumor tissue down to an individual size of less than one centimeter, which leads to a higher survival probability ${ }^{1}$.

There are three features regarding surgical cytoreduction that should be taken into consideration. The first is physiological benefit; namely, as the spread of the disease along the abdominal cavity causes disruption of gastrointestinal functions, the catabolic effect of the tumor is reduced along with reduction of the tumor mass. Secondly, sensitivity to cytostatic therapy is increased by improving vascularization of the residual tumor mass. Thirdly, the immune gain is achieved with removal of large tumor masses, which results in the increase of the natural killer (NK) cell and cytotoxic $\mathrm{T}$ lymphocyte activity in patient serum ${ }^{4}$.

There are three designated levels of cytoreductive surgery in ovarian cancer therapy. The standard approach includes total abdominal hysterectomy and bilateral salpingo-oopherectomy (TAH-BSO), supracolic omentectomy, appendectomy and paraaortic lymphadenectomy. The radical approach includes the standard approach along with the en bloc resection of the rectosigmoid colon and coloanal anastomosis (Hudson procedure). The supraradical approach includes the previous two approaches along with other digestive resections, splenectomy, and extensive ablation of the peritoneum including diaphragm stripping 4 .

Radical and supraradical surgery is validated in cases where complete or optimal cytoreduction is expected. In these cases, a five-year survival up to $50 \%$ can be expected. In patients with unresectable tumors, chemosurgical cytoreduction (neoadjuvant chemotherapy followed by surgical cytoreduction) is a better option.

The resectability criteria are age, patient condition, presence of metastasis outside the abdomen, massive peritoneal invasion, massive implants of coronary liga- ments of the liver, metastases in suprarenal lymph nodes, and massive invasion of the intestinal mesentery ${ }^{1}$. Recently, chemotherapy of ovarian cancer is carried out with taxan compounds (with paclitaxel as the first choice). If paclitaxel is used alone, it leads to remission in $36 \%$ of previously treated patients. The combination of paclitaxel and cisplatin is renowned as the most efficient combination in ovarian cancer treatment, as it achieves remission in almost $70 \%$ of patients ${ }^{6}$.

Gynecologic Oncology Group studies have shown that intravenous administration of chemotherapeutics (paclitaxel with cisplatin) in combination with intraperitoneal administration (also paclitaxel with cisplatin) in stage III patients with optimal cytoreduction (residual tumor $<1 \mathrm{~cm}$ ) leads to prolonging of the disease-free intervals by 5.5 months, and to improvement of total survival by 15.9 months $^{7}$. The outcome of therapy is generally affected by clinical stage of the disease, therefore, the five-year survival is $80 \%-100 \%$ in the first and second stages, $20 \%-40 \%$ in the third stage, and only $5 \%-10 \%$ in the fourth stage ${ }^{8}$.

\section{Patients and Methods}

The study included female patients treated for ovarian cancer in the period between January 1, 2000 and December 31, 2004 at the Department of Gynecology and Obstetrics, Osijek University Hospital Centre in Osijek, Croatia. Data collected from patient medical history, operative protocols, histopathologic and cytological findings, and patient oncologic records were retrospectively analyzed.

The study included 126 patients aged 29 to 85 . The following clinical prognostic factors were analyzed: clinical stage, age and parity. The histopathologic factors analyzed were histologic type and grade, cytological findings of ascites, and peritoneal washout. Finally, the therapeutic factors analyzed were surgical treatment applied with the level of cytoreduction, adjuvant chemotherapy, and response to chemotherapy.

Clinical stage was divided into four groups according to the 1998 FIGO criteria ${ }^{9}$. Histologic grade of the tumor was divided into four stages according to the American Joint Commission on Cancer (AJCC) ${ }^{10}$. The centrifugal residue of the ascites and peritoneal washout was stained by MGG technique and tested according to standard cytological criteria for malig- 
nant cells. When the results proved to be disputable, special staining was used to test immunologic factors.

Surgical treatment with the level of cytoreduction was determined according to the criteria used in the 2011/2002 GOG studies ${ }^{2,3}$. Adjuvant chemotherapy was administered according to standards of ovarian cancer treatment. Response to chemotherapy was described as total remission, partial remission, or progression. Remission of the disease was proven by tumor markers (CA-125), abdominal ultrasound, TV $3 \mathrm{D}$ ultrasound, $\mathrm{x}$-ray of the lungs, and computed tomography of the abdomen. All of these parameters were within physiological limits and used to determine total remission. Partial remission was considered in cases where it could be proven by these parameters, but on a smaller scale than before. If the disease was proven to be of a greater scale than before (despite treatment), then it was considered disease progression.

Analysis of survival was based on patient observation data collected from the point of diagnosis to either the point of death from the original disease (adverse outcome), or to the point of termination of observation (favorable outcome or census). The probability of survival was calculated according to the life chart method and presented visually using Kaplan-Meier curves. Statistical indicators of survival analysis are based on a log-normal data distribution. The simultaneous effect of all indicators on survival prognosis (clinical, histopathologic and therapeutic) was analyzed using the method of multivariate regression with incomplete data (Cox regression analysis). The $\chi^{2}$-test was used to determine correlation between the level of cytoreduction and chemotherapy. Reaching conclusions on statistical hypotheses was done with a significance level of $\mathrm{p}<0.05$ for all the tests applied. The SPSS for Windows software (version 17.0 SAS Institute Inc., Cary, NC, SAD) was used for statistical analysis.

\section{Results}

During the study period, 64 (50.7\%) subjects died. The median survival was 76.2 months and total fiveyear survival was $55.5 \%$. The study included patients aged between 29 and 82 . Figure 1 shows distribution of patients according to age. It is notable that the largest number of patients were aged 65-69 (15.8\%). After dividing patients into two groups according to age $(<50$ and $>50)$, younger patients were found to have

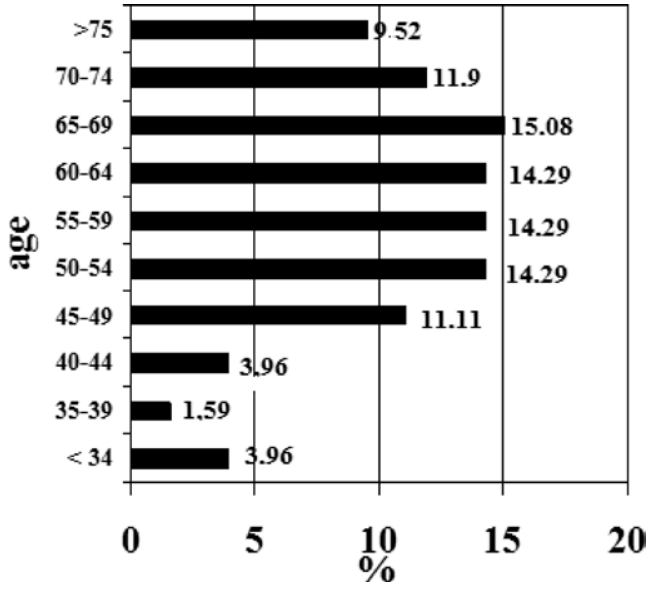

Fig. 1. Disease distribution according to patient age.

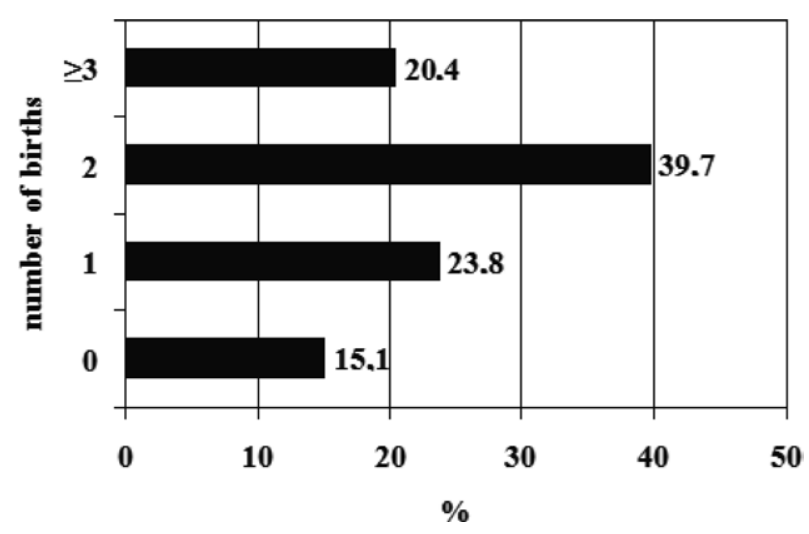

Fig. 2. Patient distribution according to parity.

better survival, but the difference was not statistically significant. Cox regression analysis showed that age was not an independent prognostic factor $(\mathrm{p}=0.309)$.

According to parity, patients were divided into groups with 0 (nulliparous), 1, 2, and 3 or more children. Figure 2 shows distribution of patients according to parity. It is noticeable that the majority of patients had two children (39.7\%). Patients with 0,1 or 2 children had better survival than those with 3 or more children. The difference was statistically significant only on univariate analysis $(\mathrm{p}<0.0001)$.

Patient distribution according to clinical stages showed that almost half of ovarian cancers were detected in the advanced third stage of the disease (Fig. 3). Patient survival according to FIGO staging was presented using Kaplan-Meier curves. The five-year survival in the first stage of the disease was best, amounting to $85 \%$, but survival dropped in higher stages and was $60 \%$ in second stage, and only $25 \%$ in 


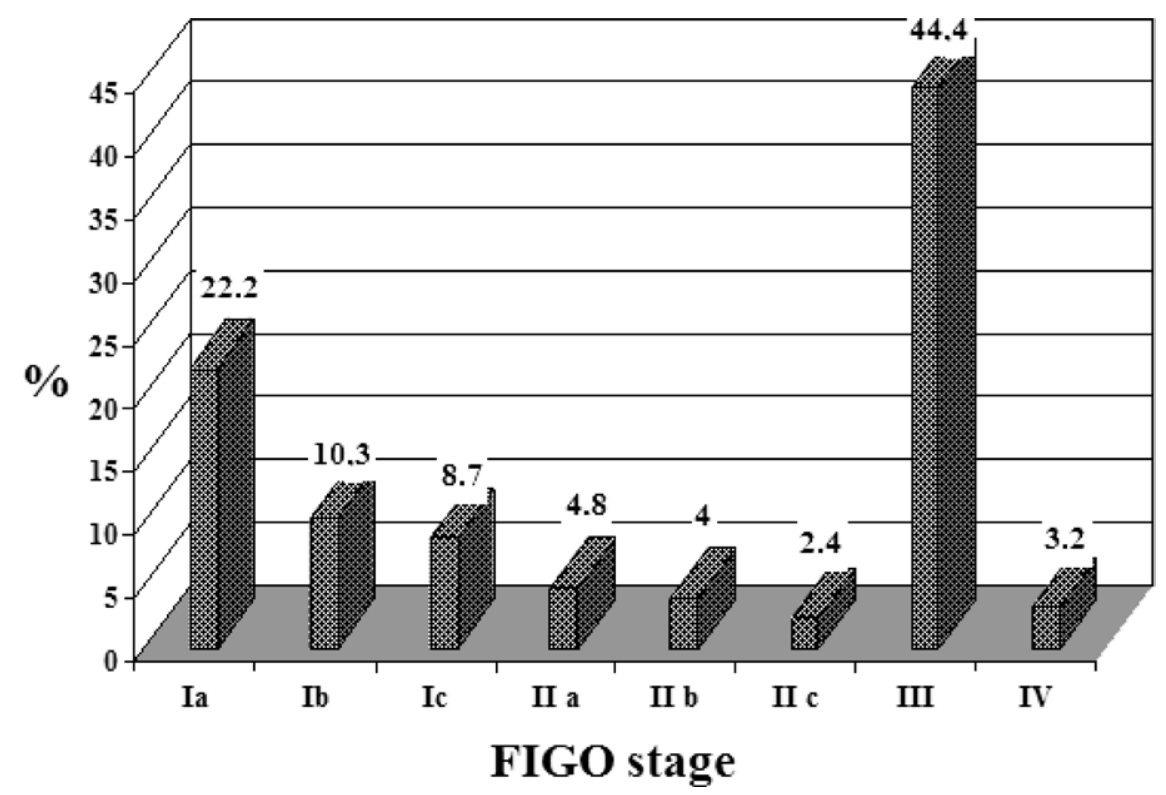

Fig. 3. Patient distribution according to FIGO stage.

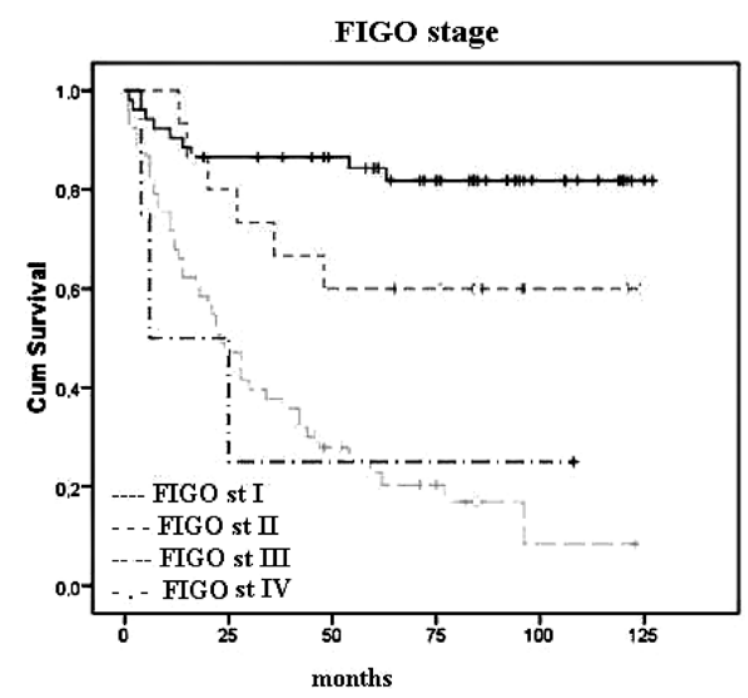

Fig. 4. Kaplan-Meier curves for overall survival according to FIGO stage.

third and fourth stages (Fig. 4). Statistical analysis yielded no statistically significant difference between the first and second clinical stages, while the difference between the first and third, and first and fourth stages indicated a statistically significantly better five-year survival in the first stage $(\mathrm{p}<0.00019)$.

The most frequent histologic type of tumor was serous carcinoma (58\%), followed by mucinous (12.7\%), undifferentiated (8.6\%), endometrioid (7.1\%), and clear cell carcinoma (4.8\%), granulosa cell tumor (3.2\%) and immature teratoma (1.5\%), while other histologic types of tumors were less frequent $(<1 \%)$. Granulosa cell tumors had the best prognosis and $100 \%$ five-year survival, whereas undifferentiated tumors had the worst prognosis with only $10 \%$ five-year survival (Fig. 5).

Figure 6 shows that ovarian tumors were most often (40\%) poorly differentiated (G3), whereas welland moderately differentiated tumors were less frequent and made up only $35 \%$ of all tumors. It should be noted that the histologic grade in pathologic findings was not determined in one-quarter of all patients. The survival according to histologic grade was presented with Kaplan-Meier curves (Fig. 7). The five-year survival of patients with well-differentiated tumors (G1) was $94.4 \%$, for moderately differentiated tumors it was $69.2 \%$, and for poorly differentiated tumors it was only $23.5 \%$. The difference in survival between well- and moderately differentiated tumors, and between well- and poorly differentiated tumors was statistically significant $(\mathrm{p}<0.0001)$. Histologic grade is a significant prognostic factor in univariate analysis, but was proven not to be an independent prognostic factor in multivariate analysis.

Ascites was present in $38.1 \%$ of patients; $89.6 \%$ of ascites were cytologically positive for malignant cells. Peritoneal washout was carried out in $53.9 \%$ of cases 


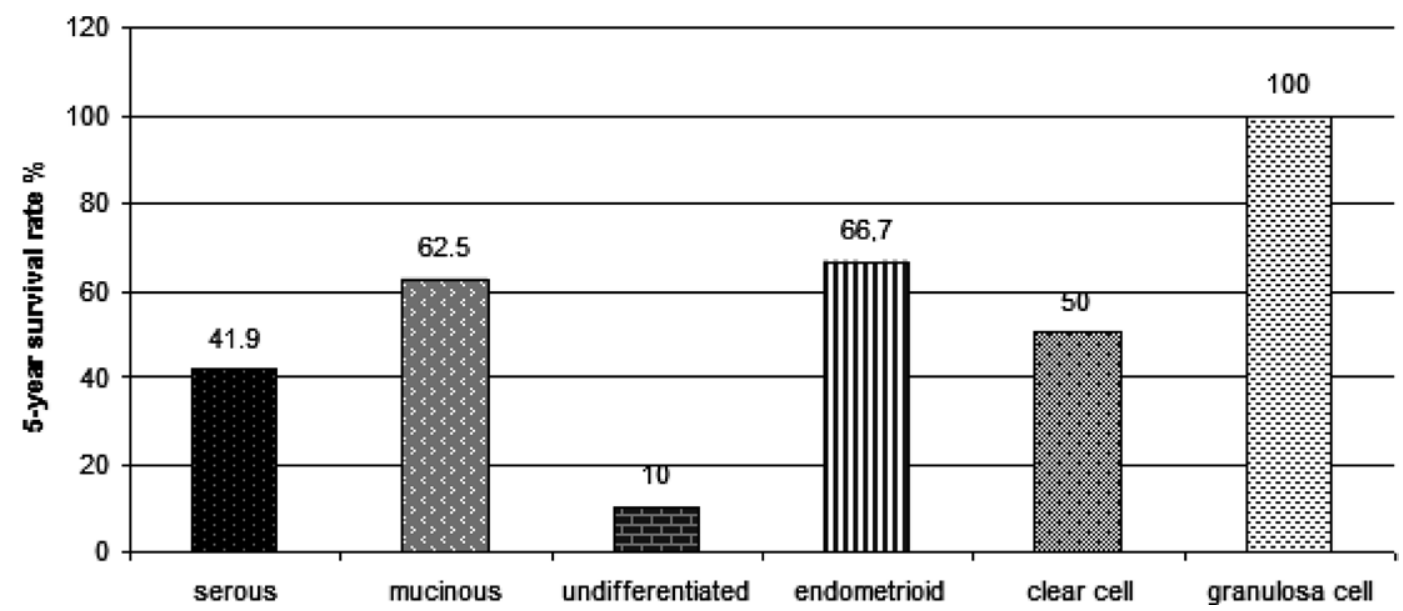

Fig. 5. Five-year survival rate according to histologic type of tumor.

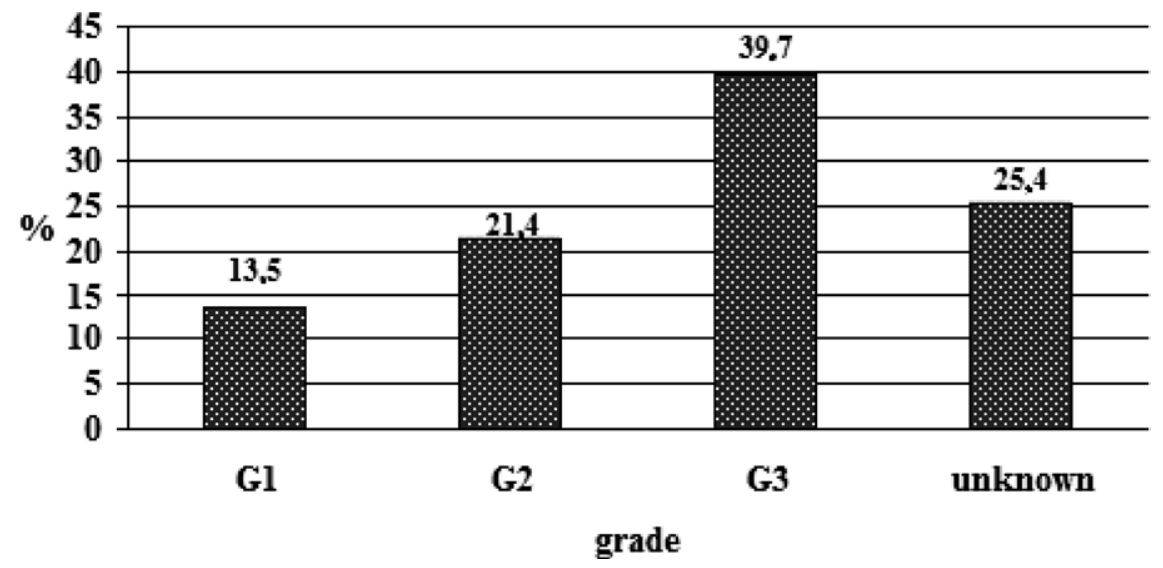

Fig. 6. Patient distribution according to histologic grade of tumor.

where there was no ascites present, and was positive in $35.3 \%$. Peritoneal washout was not carried out in $7.9 \%$ of patients (Fig. 8). Univariate analysis yielded a statistically significantly $(\mathrm{p}<0.001)$ worse survival in $\mathrm{pa}^{-}$ tients with cytologically positive findings of the ascites. There was a statistically significant difference in survival between patients whose peritoneal washout was positive and those whose washing was negative $(\mathrm{p}<0.003)$. Independent prognostic significance was not proven by multivariate analysis.

Optimal cytoreduction was carried out in almost half (49.2\%) of the primarily surgically treated patients according to the 2001/2002 GOG guidelines with residual tumor of $<1 \mathrm{~cm}$. Suboptimal cytoreduction with residual tumor of $<2 \mathrm{~cm}$ was carried out in $40.5 \%$ and explorative laparotomy in $10.3 \%$ of cases. There was a

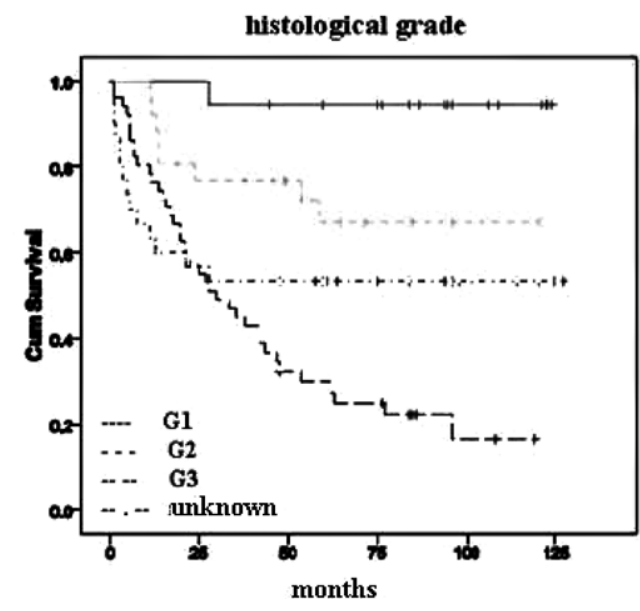

Fig. 7. Kaplan-Meier curves for overall survival according to histologic grade. 


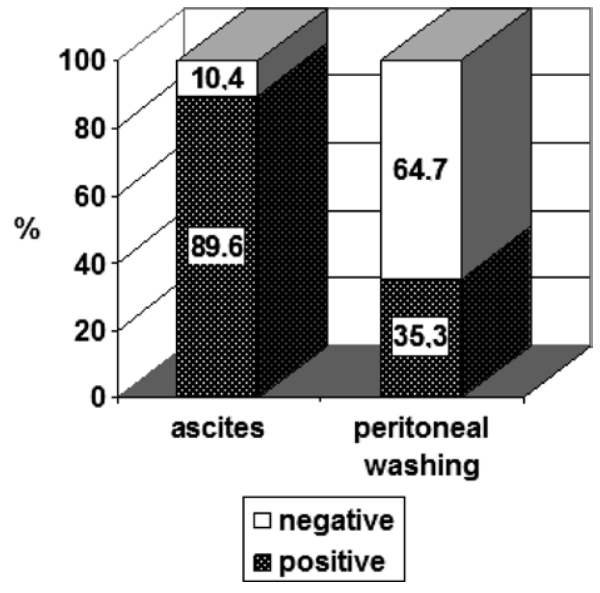

Fig.8. Presence of malignant cells in ascites or peritoneal washout.

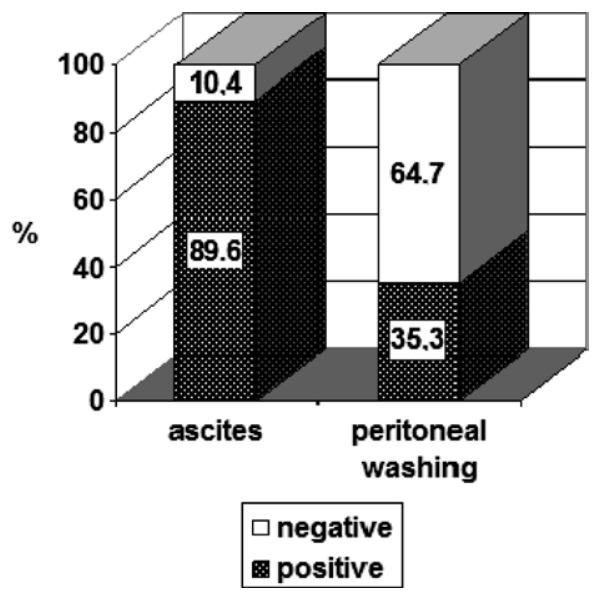

Fig.9. Kaplan-Meier curves for overall survival according to optimal cytoreduction.

significant difference in survival between patients with optimal and suboptimal cytoreduction $(\mathrm{p}=0.0001)$ (Fig. 9). Univariate analysis indicated optimal cytoreduction to be a statistically significant prognostic factor for survival. Multivariate analysis showed that among all other prognostic factors tested, only optimal cytoreduction was a statistically significant and independent prognostic factor for survival in ovarian cancer patients $(p=0.001)$.

Chemotherapy was administered to $73 \%$ of $\mathrm{pa}^{-}$ tients. Around two-thirds (66.3\%) were treated with a combination of paclitaxel and carboplatin, and 33.6\% with another kind of chemotherapy. Analysis revealed that survival depended on the type of chemotherapy, as survival in patients treated with paclitaxel amounted

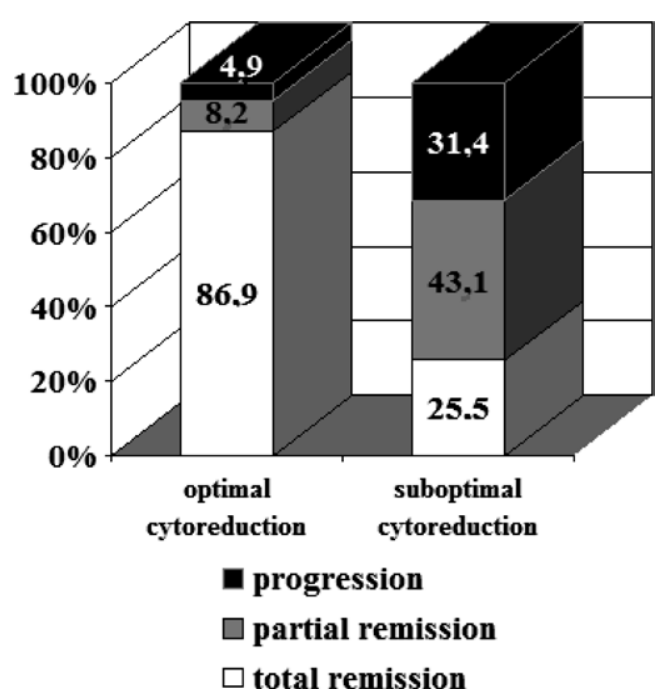

Fig.10. Overview of responses to chemotherapy depending on the level of cytoreduction.

to $55 \%$, while in those using other chemotherapeutics it was $40 \%$. However, this difference was not statistically significant. Considering type of chemotherapy, $79.4 \%$ of patients received first-line, $15.2 \%$ received second-line, and 5.4\% received third-line chemotherapy. Both univariate and multivariate analyses showed the number of lines and cycles of chemotherapy to be statistically nonsignificant and were not independent prognostic factors. It was analyzed how the level of cytoreduction influenced chemotherapy response. Data showed that there was a statistically significant difference between patients having undergone optimal cytoreduction and those having undergone inadequate cytoreductive surgery $(\mathrm{p}=0.0001)$.

As shown in Figure 10, total remission was achieved by chemotherapy and optimal cytoreduction in $86.9 \%$ of cases, but only $25.5 \%$ of patients when utilizing suboptimal cytoreduction. The patients having undergone only suboptimal cytoreduction mostly had partial remission (43.1\%). Progression of the disease occurred in $4.9 \%$ of patients undergoing optimal cytoreduction, and in astonishing $31.4 \%$ when undergoing suboptimal cytoreduction. A few of the prognostic factors tested are presented in Table 1, along with their statistical significance in univariate and multivariate analysis. As shown in this table, parity, histologic grade, presence of malignant cells in the ascites and peritoneal washout, and clinical stage had a statistically significant role in survival, whereas optimal cytoreduction was the only independent prognostic factor. 
Table 1. Prognostic value of selected prognostic factors

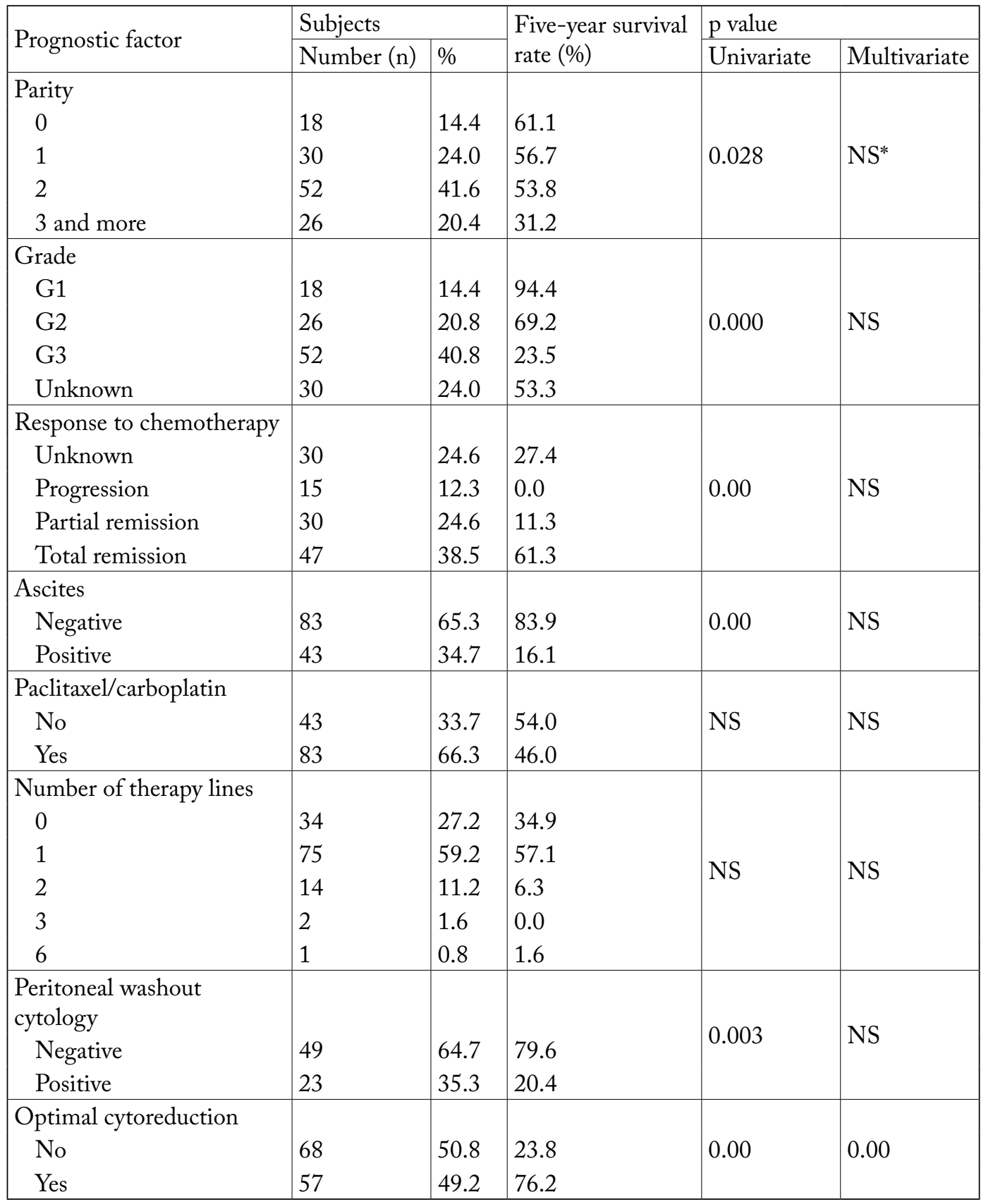

$\mathrm{NS}=$ nonsignificant

\section{Discussion}

According to the 2001/2002 GOG guidelines, the basic goal of all cytoreductive procedures is complete removal of the tumor (total cytoreduction), or reduction of the tumor down to the residual size of $<1 \mathrm{~cm}$ (optimal cytoreduction) $^{1}$.
The peak incidence of ovarian cancer in the study group was between age 65 and 69, which corresponds to literature data ${ }^{11}$. In this case, however, age was not shown to be a statistically significant variable for survival, although the group of patients above 50 years of age had worse survival than the group of younger pa- 
tients. According to the studies by Makar et al. ${ }^{12}$ and Chi et al. ${ }^{13}$, age is an independent prognostic variable when it comes to advanced ovarian cancer.

Most of the patients in this study had two children, and quite unexpectedly, the rate of nulliparous patients was $14.4 \%$. Patients with three or more children had a statistically significantly worse five-year survival. Parity was not shown to be an independent prognostic factor in multivariate analysis. The FIGO stage was, as expected, shown to be a statistically significant prognostic factor, but not independent, as stated by other authors ${ }^{14}$ Almost half of the carcinomas were detected in the advanced third FIGO stage, where the five-year survival was only $25 \%$. It was in this stage where most of the suboptimal cytoreduction and explorative laparotomy procedures took place, suggesting that the size of residual tumor rather than the stage of tumor expansion plays a key role in prognosis.

The most common histopathologic tumor type was serous cancer (58\%) with five-year survival of $41.9 \%$. Other authors report on the histopathologic tumor type to be a statistically significant prognostic factor, emphasizing that serous and endometrioid types have better prognosis than mucinous and clear cell carcinoma ${ }^{12}$.

Our results showed that poorly differentiated tumors (G3) were most frequently identified in histopathologic findings. Univariate analysis showed that grade was statistically significant $(\mathrm{p}=0.0001)$, but was not proven to be an independent prognostic factor by multivariate analysis. Retrospective research by other authors has shown the same results ${ }^{13}$.

Patients with positive ascites had a statistically significantly worse survival than those with negative ascites $(\mathrm{p}<0.001)$. Similar results were recorded in patients with positive peritoneal washout. Our study showed that positive ascites was not an independent prognostic factor, unlike the results reported by other authors ${ }^{13}$. Considering that cytological findings of malignant cells in the ascites have been incorporated in the FIGO classification, it was logical to assume that neither of the two prognostic factors would be statistically significant in multivariate analysis.

The success of surgical treatment depended on the level of cytoreduction. Half of the patients had undergone optimal cytoreduction, which was shown to be a significant prognostic factor in univariate analysis $(p<0.0001)$, while multivariate analysis indicated that optimal cytoreduction was an independent prognostic factor for survival of ovarian cancer patients $(p<0.01)$. Such data have also been reported elsewhere, but mostly for advanced ovarian cancers. A 2002 metaanalysis by Bristow et al. ${ }^{7}$ on 6885 stage III and IV epithelial ovarian cancer patients evaluated different prognostic factors for survival. Positive correlation was observed between maximal surgical cytoreduction and survival median, even in multivariate analysis. Every $10 \%$ increase of maximal cytoreduction was correlated to $5.5 \%$ increase in the survival median. Most of the studies included in this meta-analysis were defined by maximal cytoreduction of $1-2 \mathrm{~cm}$ of residual tumor. Several reports state that the goal of primary cytoreductive surgery of epithelial ovarian cancer should be a state with no residual tumor ${ }^{15-18}$. In our patients, median survival was 76.2 months regardless of the level of cytoreduction. Other studies report on median survival of 99 months ${ }^{18}$ and 106 months ${ }^{16}$, but only for patients with no residual disease. There is also report on only $23.8 \%$ survival in patients having undergone suboptimal cytoreductive treatment ${ }^{15}$.

In our study, $73 \%$ of patients received chemotherapy after surgical treatment, $63.3 \%$ of them paclitaxel/ carboplatin as first-line chemotherapy. Univariate analysis showed that survival was better in patients having received the combination of paclitaxel and carboplatin as first-line chemotherapy than in those having received other chemotherapeutics. This difference, however, was not statistically significant. This result corresponds to those reported by other authors ${ }^{7}$. The number of chemotherapy lines was shown to be statistically significant when linked to optimal surgery, but was not significant in relation to the operative procedure itself. This means that the patients having undergone optimal cytoreduction should have received a smaller number of chemotherapy lines and cycles. After analyzing the number of lines and cycles of each type of chemotherapy, our data revealed that neither the number of lines nor the number of cycles was statistically significant. The number of lines and cycles was determined by the quality of therapeutic response rather than by one of the variables tested.

The response to chemotherapy was, depending on the level of cytoreduction, of notable statistical significance. According to Eisenhauer et al. ${ }^{15}$, patients having started receiving chemotherapy after optimal cytoreductive surgery had a statistically significantly better survival. Our analysis also showed better survival, and 
this difference was statistically significant. This points to a conclusion that patients having undergone optimal cytoreduction experienced total remission after chemotherapy more often. Total remission of the disease was observed in $86.9 \%$ of patients who had undergone chemotherapy after optimal cytoreduction, but in only $25.5 \%$ of patients having undergone the same chemotherapy after suboptimal cytoreduction. The response to chemotherapy was not shown to be an independent prognostic factor in multivariate analysis.

To conclude, we can say that optimal cytoreductive treatment of ovarian cancer is an independent prognostic factor for survival, and it also improves patient response to chemotherapy.

\section{References}

1. Ćorušić A, Babić D. Diagnostics, Treatment and Prognosis of Malignant Tumors of Ovaries. Zagreb: Artsoft, 2003. (in Croatian)

2. Markman M. Intraperitoneal chemotherapy in the management of malignant disease. Expert Rev Anticancer Ther. 2001;1:142-8. DOI: 10.1586/14737140.1.1.142

3. Krivak TC, Tian C, Rose GS, Armstrong DK, Maxwell GL. A Gynecologic Oncology Group Study of serum CA-125 levels in patients with stage III optimally debulked ovarian cancer treated with intraperitoneal compared to intravenous chemotherapy: an analysis of patients enrolled in GOG 172. Gynecol Oncol. 2009;115(1):81-5. DOI: 10.1016/j.ygyno.2009.06.021

4. Di Saia PJ, Creasman WT. Clinical Gynecologic Oncology, St Louis: Mosby, 1997.

5. Fox H. Pathology of ovarian cancer. In: Kavanagh JJ, Singletary SE, Einhorn N, Depertillo AD, editors. Ovarian and Fallopian Tube Cancer. Malden-Winnipeg: Blackwell Science, 1999.

6. Trimbos JB, Vergote I, Bolis G, Vermorken JB, Mangioni C, Madronal C. Impact of adjuvant chemotherapy and surgical staging in early-stage ovarian carcinoma: European Organisation for Research and Treatment of Cancer-Adjuvant Chemotherapy in Ovarian Neoplasm trial. J Natl Cancer Inst. 2003;95:113-25. DOI: 10.1093/jnci/95.2.113

7. Bristow RE, Tomacruz RS, Armstrong DK, Trimble EL, Montz FJ. Survival effect of maximal cytoreductive surgery for advanced ovarian carcinoma during the platinum era: a metaanalysis. J Clin Oncol. 2002;20:1248-59. DOI: 10.1200/ JCO.2002.20.5.1248
8. Omura GA, Brady MF, Homesley HD, Yordan E, Major FJ, Buchsbaum HJ, Park RC. Long-term follow-up and prognostic factor analysis in advanced ovarian carcinoma: the Gynecologic Oncology Group experience. J Clin Oncol. 1991;9: 1138-50. DOI: 10.1200/JCO.1991.9.7.1138

9. Creasman WT. New gynecologic cancer staging. Obstet Gynecol. 1995;75(2):287-98. DOI: 10.1006/gyno.1995.1203

10. The American Joint Committee on Cancer. Ovary. In: The American Joint Committee on Cancer (AJCC) Cancer Staging Manual. Philadelphia: Lippincott-Raven Publishers, 1997.

11. Edmonds K. Dewhurst's Textbook of Obstetrics and Gynaecology. $8^{\text {th }}$ edn. Hoboken, NJ: John Wiley and Sons Ltd., 2012.

12. Makar A, Baekelandt M, Tropé C, Kristensen G. The prognostic significance of residual disease, FIGO substage, tumor histology, and grade in patients with FIGO stage III ovarian cancer. Gynecol Oncol. 1995;56:175-80.

13. Chi DS, Liao JB, Leon LF, Venkatraman ES, Hensley ML, Bhaskaran D, Hoskins WJ. Identification of prognostic factors in advanced epithelial ovarian carcinoma. Gynecol Oncol. 2001;82:532-7. DOI: 10.1006/gyno.2001.6328

14. Hornung R, Urs E, Serenella E, Edward W, Ursula S, Urs H, Daniel F. Analysis of potential prognostic factors in $111 \mathrm{pa}-$ tients with ovarian cancer. Cancer Lett. 2004;206:97-106. DOI: 10.1016/j.canlet.2003.10.034

15. Eisenhauer EL, Abu-Rustum NR, Sonoda Y, Aghajanian C, Barakat RR, Chi DS. The effect of maximal surgical cytoreduction on sensitivity to platinum-taxane chemotherapy and subsequent survival in patients with advanced ovarian cancer. Gynecol Oncol. 2008;108:276-81. DOI: 10.1016/j.ygyno. 2006.06.028

16. Chi DS, Eisenhauer EL, Lang J, Huh J, Haddad L, Abu-Rustum NR. What is the optimal goal of primary cytoreductive surgery for bulky stage IIIC epithelial ovarian carcinoma? Gynecol Oncol. 2006;103:559-64. DOI: 10.1016/j.ygyno. 2006.03.051

17. Eisenkop SM, Friedman RL, Wang HJ. Complete cytoreductive surgery is feasible and maximizes survival in patients with advanced epithelial ovarian cancer: a prospective study. Gynecol Oncol. 1998;69:103-8. DOI: 10.1006/gyno.1998.4955

18. Du Bois A, Reuss A, Pujade-Lauraine E, Harter P, Ray-Coquard I, Pfisterer J. Role of surgical outcome as prognostic factor in advanced epithelial ovarian cancer: a combined exploratory analysis of 3 prospectively randomized phase 3 multicenter trials: by the Arbeitsgemeinschaft Gynaekologische Onkologie Studiengruppe Ovarialkarzinom (AGO-OVAR) and the Groupe d'Investigateurs Nationaux Pour les Etudes des Cancers de l'Ovaire (GINECO). Cancer. 2009;115: 1234-44. DOI: $10.1002 /$ cncr.24149 
Sažetak

\section{PROGNOSTIČKO ZNAČENJE CITOREDUKCIJE KOD RAKA JAJNIKA - ISKUSTVO IZ ISTOČNE HRVATSKE}

\section{Z. Topolovec, T. Horvat, D. Vidosavljevic, S. Šijanovic, A. Müller-Vranješ, M. Ugljarevic, D. Milojković i S. Topolovec}

Cilj ove retrospektivne studije bio je prikazati utjecaj optimalne citoreduktivne terapije na ukupnu prognozu liječenja raka jajnika. Analizirano je nekoliko čimbenika uključujući kliničke (stupanj, dob i paritet), histopatološke/citološke (histološki tip i stupanj tumora, citološki nalaz ascitesa ili peritonealnog ispiranja) i terapijske značajke (operativni zahvat sa stupnjem citoredukcije, adjuvantne kemoterapije i odgovora na terapiju). U istraživanju je sudjelovalo 126 bolesnica liječenih tijekom petogodišnjeg razdoblja na Klinici za ginekologiju i opstetriciju Kliničkog bolničkog centra u Osijeku. Dob bolesnica bila je u rasponu od 29 do 82 godine, ukupno petogodišnje preživljavanje bilo je 55,5\%, a medijan preživljenja 76,2 mjeseca. Optimalna citoredukcija (rezidualni tumor $<1 \mathrm{~cm}$ ) provedena je u $49,2 \%$ bolesnica. Na temelju analize podataka korištena je metoda dijagrama preživljenja, $\chi^{2}$-test i Coxova regresijska analiza. Razina značajnosti je postavljena na $p<0,05$. Paritet, histološki stupanj tumora, prisutnost malignih stanica u ascitesu i peritonealnom ispiranju, kao i klinički stadij su se pokazali statistički značajni pri univarijatnoj analizi. Citoreduktivna terapija raka jajnika pokazala se značajnim prognostičkim čimbenikom i prikazana je u multivarijatnoj analizi kao neovisni prognostički čimbenik. Optimalna citoredukcija, osim izravnog učinka na preživljavanje, poboljšala je i kvalitetu terapijskog odgovora tumora na kemoterapiju.

Ključne riječi: Ovarijski tumori; Citoredukcijski kirurški postupci; Prognoza; Retrospektivne studije; Kemoterapija, adjuvantna; Hrvatska 